\title{
CZYM JEST SAKRALNY WYMIAR NATURY? FILOZOFICZNA INTERPRETACJA TWÓRCZOŚCI FRIEDRICHA HÖLDERLINA W DZIEŁACH ROMANO GUARDINIEGO
}

\begin{abstract}
Streszczenie. Głównym celem artykułu jest prezentacja sakralnego charakteru natury, analizowanej przez Romano Guardiniego (1885-1968) w opracowaniach filozoficznych poświęconych interpretacji twórczości Friedricha Hölderlina (1770-1843). Guardini prowadził swoje badania nad twórczością Hölderlina na gruncie filozofii religii. Twierdził, że w wierszach i poematach tego wybitnego myśliciela i poety szczególną rolę odgrywa natura rozumiana jako przestrzeń, w której zamieszkuje sacrum. W twórczości literackiej Hölderlina jest obecna nowa forma religijności postchrześcijańskiej, która polega na reinterpretacji symboli chrześcijańskich i metamorfozie fenomenu religijnego z rzeczywistości obiektywnej w różnorodne formy zindywidualizowane.
\end{abstract}

Słowa kluczowe: natura, sacrum, religia, nowożytność, ponowożytność, doświadczenie religijne, sekularyzacja, religijność postchrześcijańska

1. Wprowadzenie. 2. Narodziny religijności postchrześcijańskiej. 3. Teologiczna koncepcja natury w powieści Hyperion. 4. Interpretacja natury w dramacie Śmierć Empedoklesa 5. Podsumowanie.

\section{WPROWADZENIE}

20 marca 2020 r. świętowano w Niemczech 250. rocznicę urodzin Friedricha Hölderlina (1770-1843), który jest powszechnie uznawany za jednego z prekursorów klasyki weimarskiej oraz romantyzmu. W trakcie studiów w Tybindze do grona najbliższych przyjaciół tego wybitnego poety należeli Georg Wilhelm Friedrich Hegel oraz Friedrich Wilhelm Joseph von Schelling, z którymi dzielił on żywe i głębokie zainteresowanie szeroko rozumianą twórczością 
filozoficzną ${ }^{1}$. Poezja Hölderlina porusza wiele ważnych zagadnień filozoficznych i teologicznych oraz bardzo często odwołuje się do kultury starożytnej Grecji.

Rok 2020 został ogłoszony w kraju nad Renem Rokiem Friedricha Hölderlina. W ramach obchodów 250. rocznicy urodzin tego wielkiego poety zorganizowano ponad 650 wydarzeń artystycznych $\mathrm{i}$ intelektualnych (wystaw, wykładów, konferencji naukowych, koncertów itp.) $)^{2}$. Niezwykle ważnym elementem świętowania w Niemczech Roku Hölderlina było przygotowanie wielu cennych opracowań naukowych, dotyczących analizy jego niezwykle bogatej twórczości³. Za najważniejszą z nowych monografii, poświęconych temu poecie, należy uznać książkę Rüdigera Safranskiego pt. Hölderlin: Komm! ins Offene, Freund! Biographie ${ }^{4}$.

Podjęcie w ostatnim czasie nowych badań naukowych, dotyczących analizy dzieł Hölderlina, można częściowo porównać $\mathrm{z}$ renesansem twórczości tego myśliciela i poety, który nastąpił w jego ojczyźnie po I wojnie światowej. W pierwszej połowie XX wieku wielu intelektualistów europejskich realizowało nowe badania filozoficzne nad wierszami i poematami Hölderlina. Wśród najważniejszych komentatorów tego autora byli m.in. dwaj niemieccy myśliciele Hans-Georg Gadamer i Theodor Adorno oraz węgierski filozof

1 Por. E. Witschke, Hegel, Hölderlin, Schelling: Roman einer Männerfreundschaft, Tübingen 2019.

2 Por. Th. Schmidt, Hölderlin 2020. Das Jubiläumsjahr: Programm, München 2020.

3 Por. M. Ladwein, Friedrich Hölderlins griechische Seele, Stuttgart 2020; U. Gonther, J.E. Schlimme, Hölderlin: Das Klischee vom umnachteten Genie im Turm, Köln 2020; J. Link, Hölderlins Fluchtlinie Griechenland, Göttingen 2020; K. Oesterle, Wir \& Hölderlin? Was der größte Dichter der Deutschen uns 250 Jahre nach seiner Geburt noch zu sagen hat, Tübingen 2020.

4 Por. R. Safranski, Hölderlin: Komm! ins Offene, Freund! Biographie, München 2019. Rüdiger Safranski jest jednym z najbardziej znanych niemieckich filozofów współczesnych. Za szczególnie cenne należy uznać jego biografie, tłumaczone na wiele języków świata, poświęcone m.in. takim twórcom i myślicielom jak Johann Wolfgang von Goethe, Friedrich Schiller, Artur Schopenhauer, Fryderyk Nietzsche czy Martin Heidegger. 
György Lukács. Do badaczy dzieł Hölderlina należał także niemiecki myśliciel Romano Guardini (1885-1968), który opublikował w 1939 r. obszerne dzieło (568 stron) pt. Hölderlin. Weltbild und Frömmigkeit, poświęcone w całości temu autorowi ${ }^{5}$.

Guardini uważał Hölderlina za poetę-wieszcza. Twierdził, że Hölderlin nie był poetą w sensie nowożytnym jak Johann Wolfgang von Goethe, ale w znaczeniu starożytnym jak Pindar, Ajschylos czy Dante Alighieri. Dla Guardiniego Hölderlin był tym, kim po autorze Boskiej komedii nie był już nikt inny: widzącym i głosem, który wzywa. Guardini podkreślał, że Hölderlin posiadał „naturę religijną najwyższej klasy”'. Jego osobiste doświadczenie egzystencjalne było stricte religijne i zwracało się do tego, co boskie. W poetyckiej działalności Hölderlina istniało coś w rodzaju „kapłaństwa”, które skłaniało go do poetyckiego wyrażania się jako widzący i zwiastun tego, co nadchodzi.

Guardini prowadził swoje badania nad twórczością Hölderlina na gruncie filozofii religii. Twierdził, że w wierszach i poematach tego genialnego poety szczególną rolę odgrywa natura rozumiana jako przestrzeń, w której zamieszkuje sacrum. Szczególnie cenne uwagi na temat sakralnego charakteru natury można znaleźć w dwóch dziełach niemieckiego poety: w powieści Hyperion, opublikowanej w dwóch tomach w latach 1797-1799, a także w dramacie Śmierć Empedoklesa, napisanym w latach 1797-1800 i opublikowanym po śmierci autora. Rozumienie natury przez Hölderlina stanowiło dla Guardiniego ważny fragment szerszej diagnozy filozoficznej, dotyczącej zmierzchu czasów nowożytnych i narodzin nowej epoki ponowożytnej.

W jaki sposób Romano Guardini interpretował naturę? Co stanowiło specyfikę jego badań nad nowożytnością? Jaką teologiczną

5 Por. R. Guardini, Hölderlin. Weltbild und Frömmigkeit, Leipzig 1939. Guardini był niemieckim myślicielem o włoskich korzeniach. Jego poszukiwania intelektualne dotyczyły m.in. filozofii religii, etyki, historii idei, filozofii kultury, filozofii historii.

6 R. Guardini, Hölderlin, dz. cyt., 242. 
koncepcję natury zaprezentował Hölderlin w powieści Hyperion? $\mathrm{W}$ jaki sposób niemiecki poeta interpretował naturę w dramacie Śmierć Empedoklesa? Czy można mówić o narodzinach nowej religijności w twórczości poetyckiej Hölderlina? Głównym celem artykułu jest prezentacja sakralnego charakteru natury, analizowanej przez Romano Guardiniego w opracowaniach filozoficznych poświęconych interpretacji twórczości Friedricha Hölderlina.

\section{NARODZINY RELIGIJNOŚCI POSTCHRZEŚCIJAŃSKIEJ}

Jedną z najbardziej oryginalnych koncepcji filozoficznych Guardiniego jest teza dotycząca zmierzchu nowożytności i narodzin nowej epoki ponowożytnej. W 1950 r. ukazała się jego ważna książka pt. Das Ende der Neuzeit ${ }^{7}$. W tej monografii została zaprezentowana analiza nowożytności nie pod kątem społecznym czy politycznym, ale w perspektywie filozoficznej i kulturowej. W pewnym sensie Guardini antycypował o kilkadziesiąt lat współczesną dyskusję na temat specyfiki postmodernizmu, ponowoczesności czy epoki ponowożytnej ${ }^{8}$. Twierdził, że istnienie człowieka opiera się na czterech elementach: naszym własnym bycie (unser eigenes Sein), ojczyźnie (Heimat), ojczyźnie w czasie (Heimat im Zeitlichen) i naturze (Natur) $)^{9}$.

Ojczyzna w sensie przestrzennym jest jednością ludu i kraju, całością w wymiarze etnologicznym i geograficznym, jednością świadomości historycznej. Wszystkie elementy tworzące ojczyznę jednoczą się w fenomenie języka. Ojczyźnie rozumianej jako nasze miejsce w przestrzeni odpowiada ojczyzna w czasie, która wyraża nasze zakorzenienie w historii. Ojczyzna w czasie wywiera wielki wpływ na życie człowieka. „Ten wpływ trafia w samo sedno. Dotyczy

7 Por. R. Guardini, Das Ende der Neuzeit. Ein Versuch zur Orientierung, Basel 1950.

8 Por. A. Kobyliński, Modernità e postmodernità. L'interpretazione cristiana dell'esistenza al tramonto dei tempi moderni nel pensiero di Romano Guardini, Roma 1998.

9 Por. A. Kobyliński, Historia i wolność według Romano Guardiniego, w: Konteksty podmiotowej świadomości, red. R. Moń, E. Podrez, Olecko 2003, 217-226. 
sposobu, w jaki funkcjonuje życie państwowe i społeczne; sposobu, w jaki ludzie żyją dla siebie i dla innych; tworzenia dzieł sztuki i ich użytkowania; bezpośredniego nastawienia w byciu" ${ }^{10}$.

Pytania dotyczące interpretacji własnej ojczyzny w czasie doprowadziły Guardiniego do podjęcia badań filozoficznych związanych z kryzysem nowożytności i narodzinami epoki ponowożytnej. Jego zdaniem kluczowym pojęciem nowożytnej wizji człowieka jest kategoria autonomii. Nowożytność interpretowała byt jako naturę, podmiot i kulturę. Potrójna autonomia - natury, podmiotu i kultury - stała się podstawowym paradygmatem nowożytności. Analizując trzy podstawowe kategorie nowożytności, Guardini w połowie XX wieku doszedł do wniosku, że zmierzają one do swego kresu. Samowystarczalna natura, autonomiczny podmiot i kultura żyjąca według swych własnych norm nie są już kategoriami ożywiającymi bieg dziejów. Kryzys tych kategorii oznacza zmierzch epoki, która na nich się opierała.

Od połowy ubiegłego stulecia Guardini twierdził, że natura nie jest już tą, o której pisali poeci w XVII czy XVIII wieku, że jest sakralną „matką naturą", ponieważ stała się przedmiotem naukowo-technologicznego panowania ze strony człowieka. $Z$ kolei metamorfoza podmiotu polega na tym, że nie jest on już autonomicznym panem siebie, ale staje się coraz bardziej człowiekiem masowym, który traci swoją indywidualność. Podobnie też i kultura nie jest już jedynie światem twórczości człowieka i jego wyzwoleniem, ale staje się coraz bardziej przestrzenią, w której człowiek - wykorzystując swoją władzę i kreatywność - zagraża samemu sobie poprzez własne wytwory. Kryzys podstawowych kategorii nowożytności oznacza narodziny nowej epoki, którą Guardini nazywa epoką ponowożytną.

Kultura ponowożytna jest zasadniczo kulturą masową, która zastępuje arystokratyczną kulturę nowożytności. Klimat kulturowy

10 R. Guardini, Ethik. Vorlesungen an der Universität München (1950-1962), t. 1-2, Mainz - Paderborn 1993, 560. 
ponowożytności określają przede wszystkim wartości władzy i panowania. Ponowożytne panowanie człowieka nad światem nie jest podobne do panowania króla, który respektuje porządek metafizyczny egzystencji, ale do panowania dyktatora, który nie szanuje istoty rzeczy i dąży do całkowitego podporządkowania sobie tego, co istnieje. Kultura ponowożytna promuje już tylko niektóre wartości humanistyczne, ale jest także zagrożeniem dla ludzkości. Mając na uwadze tragiczne doświadczenia II wojny światowej, Guardini podkreśla znaczenie różnych zagrożeń związanych z funkcjonowaniem systemów totalitarnych i nowych form technicznego panowania człowieka nad światem ${ }^{11}$.

Guardini twierdzi, że autonomiczne rozumienie natury w epoce nowożytnej zawierało elementy religijne i sakralne. W nowożytności natura stanowiła przestrzeń, w której zamieszkuje sacrum. Była ona traktowana jako rzeczywistość samowystarczalna. W epoce nowożytnej niektórzy myśliciele twierdzili, że zasada przyczynowości występuje tylko w obrębie natury, natomiast nie odnosi się do relacji istniejącej między naturą a jakąś formą rzeczywistości, która ją transcenduje. W nowożytnej wizji świata nie ma nic poza naturą. Natomiast jedną z najważniejszych cech epoki ponowożytnej jest naukowo-technologiczne panowanie człowieka nad światem natury i utrata jej sakralnego wymiaru. Guardini ukazuje na przykładzie twórczości Hölderlina, czym był dla nowożytności sakralny wymiar natury i na czym polega różnica między XX stuleciem a epoką historyczną, w której żył i tworzył autor powieści Hyperion.

Dla Guardiniego sacrum jest czymś tajemniczym i jednocześnie czymś określonym, czymś obcym i jednocześnie czymś intymnym. Wyłania się ze świata, ale prowadzi w inny wymiar. Sacrum nie należy do świata. Pozostaje obce w relacji do wszystkiego, co ziemskie, ale jednocześnie zachowuje więź ze światem, ponieważ się z niego

11 Por. A. Kobyliński, Etos człowieka prometejskiego. Romano Guardiniego ocena współczesnej kultury, władzy i techniki, Społeczeństwo (2005)1, 117-131. 
wyłania; jest więc - jak mawiał Hölderlin - „bliskie z daleka” ${ }^{12}$. Natomiast $\mathrm{w}$ relacji do człowieka sacrum jest przede wszystkim czymś darowanym. Dla Guardiniego sacrum nie jest wytworem potrzeby religijnej. Nie przedstawia zobiektywizowanej projekcji dążeń lub relacji duchowych. Każde autentyczne doświadczenie religijne implikuje pewność, że to, co nam wychodzi naprzeciw, jest samo w sobie rzeczywiste i posiada obiektywne znaczenie.

Guardini twierdzi, że wraz z Hölderlinem rozpoczął się proces tworzenia nowej postchrześcijańskiej religijności, który doprowadził do Fryderyka Nietzschego i znalazł swoje wypełnienie w twórczości Rainera Marii Rilkego ${ }^{13}$. Istotą nowej religijności nie jest negacja sacrum i zmierzch bogów, ale sekularyzacja wiary chrześcijańskiej rozumiana jako reinterpretacja symboli chrześcijańskich i metamorfoza fenomenu religijnego z rzeczywistości obiektywnej w różnorodne formy zindywidualizowane. Rilke oraz Hölderlin są interpretowani przez Guardiniego nie jako zwykli poeci, ale jako prorocy czasu, który nadchodzi: jako wieszcze nowej epoki sekularyzacji naznaczonej przez religijność postchrześcijańską ${ }^{14}$.

Według Guardiniego poezja Hölderlina wyraża przede wszystkim ból spowodowany zniknięciem żywej mocy Boga i kryzysem religijnym epoki nowożytnej. Twórczość tego niemieckiego poety jest poszukiwaniem boskości w epoce stopniowej utraty tego, co święte i religijne. $\mathrm{W}$ świecie pozbawionym świętości zamieszkana ziemia staje się ziemią obcą. Człowiek, który ją zamieszkuje, oddalił się od Boga lub bogów. Hölderlin wyraża w swoich wierszach świadomość ludzi nowożytnych, którzy utracili poczucie boskości. Guardini

12 Por. B. Maj, Poetica degli elementi e concezioni dell'uomo in „Mnemosyne” (Entwurf) di Friedrich Hölderlin, in: Natura e sentimenti, a cura di R. Milani, Milano 2000, 55-62.

13 Por. A. Kobyliński, Sekularyzacja religii w twórczości Rainera Marii Rilkego i Gianniego Vattima, Studia Philosophiae Christianae 52(2016)3, 27-50.

14 Por. E. Kathrein, Christentum in apokalyptischer Welt: Eine Anfrage an Friedrich Hölderlin, Berlin 2018; E. Nyske, Język neopentekostalny. Strategie konwersacyjne interlokutorów, Przegląd Religioznawczy 271(2019)1, 159-175. 
twierdzi, że sam Hölderlin boleśnie tęskni za tym, co święte. Bohaterowie poezji Hölderlina nie są ludźmi samowystarczalnymi, ale istotami zależnymi od sił, które ich przekraczają.

Aby odnaleźć sacrum w epoce śmierci Boga, która jest czasem skrajnego ubóstwa duchowego, ponieważ nie ma już „bogów, którzy uciekli”, a jeszcze nie ma tych, którzy „nadchodzą”, Hölderlin odkrywa boskość natury. Rozumie naturę jako „wielką jedność bytu” oraz jako „całość”. Natura, która czasami jest również nazywana „światem”, staje się pojęciem obecnym w całej twórczości autora dramatu Śmierć Empedoklesa. Dla Hölderlina natura nigdy nie ogranicza się do bycia empirycznym przedmiotem badań naukowych. Nie można też jej redukować do zwykłej sumy przedmiotów czy organizmów żywych.

"Jest to wielki kontekst - pisze Guardini - w którym każda indywidualna istota stanowi element całości, a całość przejawia się $\mathrm{w}$ formie jednostkowej. Wszystko powstaje z tajemniczego źródła i powraca do niego. Dla Hölderlina natura jest rzeczywistością ostateczną. Jest ponad rzeczą jednostkową o szczególnej charakterystyce, ponad pojedynczym człowiekiem obdarzonym własną naturą, ale także ponad boskimi mocami. Wszystko, co można nazwać, znajduje się w obrębie natury. Jest ona tym, co autentyczne i niezbędne. Natura stanowi sakralne Wszystko, poza którym nic innego nie istnieje"15.

Warto w tym miejscu zauważyć, że nowe formy religijności obecne w twórczości Hölderlina stały się w XX wieku przedmiotem badań filozoficznych nie tylko Guardiniego, ale także wielu innych myślicieli. Jednym z nich był Martin Heidegger. W roku akademickim 1934/35 Guardini i Heidegger przygotowali dwa wykłady monograficzne poświęcone twórczości autora dramatu Śmierć Empedoklesa. Pierwszy z nich prowadził w Berlinie zajęcia pt. Wiara i religijność Friedricha Hölderlina, natomiast drugi prowadził we Fryburgu Bryzgowijskim

15 R. Guardini, Hölderlin, dz. cyt., 179. 
wykład pt. Germanie, nawiązujący do zbioru hymnów Hölderlina o tym samym tytule ${ }^{16}$.

Heidegger nazywał Hölderlina "poetą poezji” i twierdził, że słowa poety mogą być początkiem odpowiedzi na pytanie o sens bycia. Najgłębszej odpowiedzi na tego rodzaju pytania udziela nie tyle metafizyka, ile poezja. Heidegger nazywał Hölderlina najbardziej niemieckim z niemieckich poetów i twierdził, że jego twórczość może prowadzić do odnowienia Dasein ${ }^{17}$. Autor Bycia i czasu rozpoczął badania filozoficzne nad twórczością Hölderlina ok. 1930 r., stwierdzając ubóstwo i nieadekwatność stosowanego wcześniej języka metafizycznego. Heidegger doszedł do wniosku, że ubóstwo językowe jest ściśle związane z niemożnością uchwycenia istoty bycia. Dlatego od lat 30. XX wieku głównym narzędziem analizy filozoficznej stało się dla niego myślenie poetyzujące, które odsłania tajemnicę bycia ${ }^{18}$.

Heidegger dostrzegał rolę, jaką w twórczości Hölderlina odgrywa nowa religijność. Szczególną uwagę zwracał on na koncepcję „ucieczki bogów”. Hölderlin celebruje w swojej poezji pamięć o bogach greckich, którzy są nieobecni. Alessandro Stavru podkreśla, że ta forma pamięci poetyckiej miała wpływ w dziełach Heideggera na nową interpretację bycia po „zwrocie” (Kehre) dokonanym w jego filozofii ${ }^{19}$. Autor Bycia i czasu twierdził, że istotą nowej religijności człowieka współczesnego jest doświadczenie nieobecności Boga i oczekiwanie na jego nadejście.

Heideggerowska koncepcja oczekiwania jest głęboko zakorzeniona w myśli Hölderlina. Heidegger przejmuje od autora powieści Hyperion pojęcie „odbóstwienia” świata. W Hölderlinowym doświadczeniu

16 Por. A. Knoll, Glaube und Kultur bei Romano Guardini, Paderborn 1993, 315.

17 Por. O.A. Böhmer, O. Höffe, Brüder im Geiste - Heidegger trifft Hölderlin, Freiburg im Breisgau 2019.

18 Por. F. Brencio, Foundation and poetry. Heidegger as a reader of Hölderlin, Studia Philosophiae Christianae 49(2013)4, 180-200.

19 Por. A. Stavru, Hölderlin und die „Flucht des Göttlichen“. Martin Heidegger und Walter F. Otto in Rom (1936-1937), Studi Germanici 39(2001)2-3, 269-310. 
dziejów, wraz ze zjawieniem się Chrystusa i Jego śmiercią, nadchodzi kres Dnia Bogów. Według niemieckiego poety, epokę nowożytną określa najgłębiej „niestawiennictwo Boga”, a nawet Jego brak. Doświadczany przez Hölderlina brak Boga nie kwestionuje religii chrześcijańskiej. „Brak Boga - twierdzi Heidegger - oznacza, że żaden Bóg nie skupia już na sobie ludzi i rzeczy w sposób oczywisty i jednoznaczny i że nie składa już, takim skupianiem, dziejów świata pozwalając w nich przebywać ludziom. Wszelako brakiem Boga daje o sobie znać coś gorszego. Nie tylko zbiegli bogowie i zbiegł Bóg, lecz w dziejach świata wygasł blask boskości. Czas Nocy Świata jest marnym czasem, gdyż marnieje coraz bardziej. Zmarniał aż tak, że nie potrafi już rozpoznać, iż brak Boga jest właśnie brakiem" 20 .

Dla Heideggera nasz czas, w którym żyjemy, jest czasem nieobecności bogów, czasem ich ucieczki. Trzeba zatem tworzyć ciszę przed nadejściem ostatniego Boga. Jego oczekiwanie wymaga długiego przygotowania. Ostatni Bóg ma dla Heideggera wyjątkowe znaczenie i przekracza wszystkie dotychczasowe pojęcia boskości, zawarte w koncepcjach monoteistycznych, panteistycznych czy ateistycznych. Ostatni Bóg nie jest końcem, lecz innym początkiem niezmierzonych możliwości naszych dziejów. Ze względu na niego, dotychczasowe dzieje nie mogą się wyczerpać, lecz muszą zostać doprowadzone do swego końca.

Warto w tym miejscu podkreślić zasadniczą różnicę istniejącą między interpretacją twórczości poetyckiej Hölderlina zaproponowaną przez Heideggera oraz analizami wypracowanymi przez Guardiniego. Włoski filozof Giorgio Penzo twierdzi, że najważniejsza różnica polega na odmiennym stosunku do sfery sacrum. Dla Guardiniego autentycznym modelem sacrum jest model Boga obecny w chrześcijaństwie, natomiast dla Heideggera autentyczny model sacrum polega na tym, aby to, co naprawdę należy do wymiaru sakralnego rzeczywistości nie było przejmowane przez nieautentyczne

20 M. Heidegger, Drogi lasu, tłum. z niem. J. Gierasimiuk i in., Warszawa 1997, 217. 
formy sacrum, a takie ryzyko - jego zdaniem - może pojawić się w chrześcijaństwie lub w każdej innej religiii ${ }^{21}$.

\section{TEOLOGICZNA KONCEPCJA NATURY W POWIEŚCI HYPERION}

Dzieło Hölderlina pt. Hyperion jest powieścią epistolarną, która składa się z listów skierowanych przez tytułowego bohatera do jego przyjaciela Bellarmina, listów Hyperiona napisanych do jego przyjaciólki Diotimy oraz listów tej ostatniej skierowanych do Hyperiona. Głównymi bohaterami powieści jest dwoje kochanków: Hyperion i Diotima. Hyperion jest młodym mężczyzną, który żyje pod koniec XVIII wieku i dąży do jedności w chaosie swego istnienia. Hyperion opowiada $\mathrm{w}$ swoich listach o swoim dzieciństwie i młodości spędzonej w kontakcie z naturą. Dzięki mądremu nauczycielowi Adamasowi, Hyperion zrozumiał bardzo wcześnie zarówno jedność natury i historii starożytnej, jak i heroiczną historię swojej ojczystej Grecji. Adamas ujawnił młodemu Hyperionowi bogactwo przyrody i wprowadził go do świata bohaterów Plutarcha i zaczarowanej krainy greckich bogów. $Z$ drugiej strony ucieleśnieniem tego wszystkiego, co oznacza starożytną grecką naturę i kulturę staje się dla Hyperiona Diotima, jego ukochana.

Guardini twierdzi, że Hölderlin w swojej powieści Hyperion pokazuje, w jaki sposób natura wkracza w ruch dzięki człowiekowi, doświadczając historii. Zgodnie z filozofią dziejów Hölderlina, tylko w człowieku natura przeżywa swoje przeznaczenie. Aby natura mogła doświadczyć w ludzkich bohaterach swojego przeznaczenia i własnego wymiaru historycznego, Hölderlin dokonuje maksymalnej stylizacji, pozostawiając ich prawdziwymi ludźmi. Dzięki takim bohaterom przyroda wkracza w przestrzeń historyczną. W ten sposób

21 Por. G. Penzo, L'interpretazione di Hölderlin in Romano Guardini, filosofo dell'esistenza, w: La Weltanschauung cristiana di Romano Guardini, red. S. Zucal, Bologna 1988, 458. 
natura jako całość istniejącej rzeczywistości znajduje w człowieku swoją indywidualną formę.

Szczególny przykład sytuacji, w której natura znajduje swoją indywidualną formę w osobie ludzkiej, stanowi Diotima. Jest ona głęboko zjednoczona z naturą i napełniona prawdziwą miłością serca. Natomiast Hyperion stanowi dokładne przeciwieństwo duszy Diotimy. O jego zachowaniu decydują myśli autodestrukcyjne. Jest on ukierunkowany na działania o charakterze zewnętrznym. To człowiek, któremu brakuje wewnętrznej powagi. W konsekwencji Hyperion jest niestały w swoich uczuciach i decyzjach. Cała fabuła tej powieści rozgrywa się w przestrzeni natury rozumianej jako wielka jedność bytu, którą Hölderlin prezentuje w opisach krajobrazu czy pór roku i dnia. Natura jest związana z losem bohaterów, który zależy od tego, w jaki sposób oni w niej wzrastają. Los bohaterów Hölderlina zależy od tego, czy oddzielają się oni od natury, czy też pozostają z nią zjednoczeni. Ścisły związek z naturą jest gwarancją ich szczęścia i powodzenia życiowego.

Guardini podkreśla, że Hölderlin interpretuje naturę poprzez losy bohaterów swoich utworów. Moc natury objawia się w ich życiu. Szczególnym przypadkiem jest Diotima. Będąc najczystszym wcieleniem i najbardziej wymownym obrazem natury, zawsze pozostaje prawdziwą osobą, która pojawia się „w lśniącej doskonałości”. Postać Diotimy ujawnia „delikatną moc, płonącą głębię, powagę, która kocha, otwartość życia i śmierci na wartości, a zatem absolutną zdolność do akceptacji przeznaczenia”22. Diotima „kocha za dużo i żyje pod wpływem impulsów serca, jest wrażliwa na wartości, ma wyjątkową wewnętrzność i zdolność przynależności. Jest miłością"23. W osobie Diotimy bycie rozkwita, tajemnica się otwiera, a całość egzystencji staje się obecna. Wydaje się, że postać Diotimy stanowi literacką odpowiedź Hölderlina na sceptycyzm religijny epoki oświecenia.

22 R. Guardini, Hölderlin, dz. cyt., 502.

23 Tamże, 503. 
"Jeśli nieśmiertelność, dusza, Bóg to tylko postulaty praktycznego rozumu, jeśli ewidentna jest tylko natura - to Hölderlin szuka nieśmiertelności, duszy i Boga w naturze. Dochodzi do rezultatów, wychodząc od panteistycznej przesłanki, że świat i Bóg to jedno, co w ówczesnej filozofii natury wyrażało się w odkryciu kreacyjnej siły natury. Natura to już nie tylko naturata, nieme, pasywne stworzenie, oczekujące zbawienia, ale i naturans, siła tworząca i samozbawiająca, która działa również w jednostkowym człowieku. Wzorem takiego człowieka jest Diotima, wystylizowana na świętą natury, w której procesy natury odbywają się w sposób niezakłócony, idealny, podobnie jak w chrześcijańskich świętych w niezakłócony sposób realizuje się wola Boża. I podobnie jak przez świętych łaska Boga sięga zwykłych ludzi, tak przez Diotimę zbawcza siła natury sięga Hyperiona, ale przede wszystkim rozlewa się na otoczenie, tak że osobowość Diotimy udziela się naturze i to, co »bezduszne«, uzyskuje duszę"24.

Natura, o której mówi Hölderlin w powieści Hyperion, stanowi boską rzeczywistość. Jest to „pierwotna boskość”, która nigdy się nie zmienia. Jeśli natura jest boska, to bogowie nie istnieją już ponad nią. Bogowie są tylko w naturze; oni żyją w jej sercu. Bogowie są bogami świata natury. Natura nie jest więc po prostu bogiem, ale jest czymś więcej niż może wyrazić słowo „bóg” w znaczeniu określonym przez Hölderlina. Boska natura w ujęciu niemieckiego poety jest niewinna, pełna szczęścia i świętości. Jest nieśmiertelna i nie zna zachodu słońca, ponieważ należy do niej boska witalność. Śmierć nie dotyka natury, ponieważ łączy ją boska miłość, a będąc sferą życia, nie może jej zagrozić żadna forma zniszczenia.

W twórczości Hölderlina natura jawi się jako całość doskonale zjednoczona mocą ducha. Natura-wszystko oznacza, że w świecie nie ma mitycznego bólu oddzielenia i nie ma podziału na bycie wspólne

24 E. Szumani, Teologiczna koncepcja natury w „Hyperionie” Hölderlina, w: Arcydzieła literatury niemieckiej. Szkice, komentarze, interpretacje, red. E. Białek, G. Kowal, Wrocław 2011, 10. 
i bycie jednostkowe. Każdy człowiek może komunikować się z Całością dzięki mocy ducha, który nie wykracza poza sferę natury. „Tylko wychodząc od ducha - stwierdza Guardini - można zrozumieć, co Hölderlin rozumie przez słowo »natura«: ani naukowy fakt fizycznej i psychicznej rzeczywistości, ani filozoficzny fakt całości istnienia. Natura jest tym, co żyje i dominuje, co znajduje się wewnątrz i na zewnątrz, co jest obecne między centrum a całością, co jest rozczłonkowane, a jednocześnie skoncentrowane we wnętrzu” 25 .

\section{INTERPRETACJA NATURY W DRAMACIE ŚMIERĆ EMPEDOKLESA}

W dramacie Śmierć Empedoklesa Hölderlin nawiązuje do historycznej postaci Empedoklesa z Agrigentu na Sycylii, który był znanym starożytnym poetą, filozofem, uzdrowicielem. Niektórzy nazywali go „półbogiem”. Głównym tematem tego utworu jest ukazanie człowieka w obliczu tajemnicy natury oraz prezentacja koncepcji „poetyckiej indywidualności", jaką stworzył Hölderlin ${ }^{26}$. Podobnie jak w powieści Hyperion, także w dramacie Śmierć Empedoklesa natura jest przedstawiona jako jedna wielka Całość: poza nią nie ma nic, także bóstwa istnieją w jej granicach. Ta wielka Całość odnosi się nie do rzeczywistości empirycznych, ale do rzeczywistości numinosum, którą można rozpoznać tylko i wyłącznie w doświadczeniu religijnym. W konsekwencji konieczne jest przyjęcie perspektywy duchowej, aby stwierdzić, że ma sens „ewangelia natury ogłoszona przez Hölderlina"27.

Guardini twierdzi, że w porównaniu z powieścią Hyperion, w dramacie Śmierí Empedoklesa natura robi krok do przodu: zamiast człowieka, działa ona na pierwszym planie i nie jest już tylko obszarem ludzkiej egzystencji, ale sama podejmuje działania. Podczas gdy

25 R. Guardini, Hölderlin, dz. cyt., 522.

26 Por. M. Endres, „Poëtische Individualität". Hölderlins Empedokles-Ode, Berlin 2014.

27 R. Guardini, Hölderlin, dz. cyt., 595. 
w Hyperionie natura była światem, w którym ludzie żyją i działają, w Śmierci Empedoklesa staje się bezpośrednim odpowiednikiem głównego bohatera i uzyskuje charakter podmiotowy.

Empedokles stał się dla Hölderlina człowiekiem o imponującej wielkości i wcieleniem ludzkiej uniwersalności. Jego intymność nie należała do nikogo. Hölderlin zauważa, że Empedokles nie czuł się zbyt mocno przywiązany do swojego przyjaciela Pauzaniusza ani do ukochanej Panthei - cichej, skupionej kapłanki Westy, będącej reinkarnacją Diotimy i obdarzonej nieograniczoną siłą miłości. Empedokles Hölderlina żyje w samotności, z której pochodzi jego twórcza iskra. „Półbóg” z Agrigentu idzie między ludzi tylko po to, by działać. Dobrze odnajduje się w „ogrodzie”, który stanowi poetycką figurę natury oraz jej intymnej harmonii i przyjaznych relacji z człowiekiem. W przestrzeni „ogrodu” Całość natury staje się obecna i patrzy życzliwie na człowieka. Los Empedoklesa nie wynika $\mathrm{z}$ jego kontaktów $\mathrm{z}$ innymi ludźmi, ale $\mathrm{z}$ jego więzi, która łączy go z absolutnymi siłami natury. Źródłem jego istnienia jest „głęboka jedność z Całością i jej bóstwami”28. Guardini zauważa jednak, że w przypadku Empedoklesa została zachowana równowaga między jednostką a Całością: „półbóg” z Agrigentu pozostaje pojedynczą postacią niosącą Całość samą w sobie i trwa na swoim miejscu żyjąc w Całości.

Ten szczęśliwy okres jedności nie trwa jednak wiecznie. „Półbóg” z Agrigentu zapomniał o odległości, która zawsze oddzielała go od bogów, dokonując świętokradztwa. Empedokles złamał równowagę istniejącą między nim a naturą, a potwierdzając swoją własną istotę, próbował ujarzmić Całość. Zakwestionował koncepcję odrębnych boskich istot i ogłosił Całość, w której każdy bóg wyraża własną naturę na swój sposób. Empedokles opuścił Agrigent, szukając schronienia w samotności. Potem rozpoznał swoją winę i otrzymał przebaczenie 
bogów. Mimo zadowolenia z pojednania nie wrócił do swojego miasta i rzucił się do krateru Etny.

Guardini zauważa, że „półbóg” z Agrigentu w narracji Hölderlina jest postacią tragiczną. Będąc „półbogiem”, podobnie jak mityczni bohaterowie, powinien kształtować ludzką egzystencję poprzez siły twórcze. Jego postać bardziej przypominała postać Chrystusa niż greckich bogów, którzy „nie mają tego, co wewnętrzne”29. Dusza Empedoklesa, w przeciwieństwie do greckich bogów, jest delikatna i głęboka. Brakuje mu jedynie uczciwości, aby mógł wykonywać swoją posługę. Pozostaje jednak zawsze postacią głęboko dionizyjską, pozbawioną równowagi apollińskiej.

Guardini twierdzi, że dramat Śmierć Empedoklesa przedstawia tajemnicę człowieka w obliczu wielkości natury. Natura okazuje się tajemnicą w swojej wielkości, pięknie i sile. Ale jest też tajemnica człowieka poświęconego naturze. Pojedynczy człowiek jest zawsze poddany wielkim ponadosobowym mocom ducha czasu i przeznaczenia. Historyczne istnienie człowieka w ujęciu Hölderlina jest także uwarunkowane przeszłością, czyli światem umarłych, którzy w wizji niemieckiego poety wydają się naprawdę powracać. Pomimo wszystkich niedoskonałości wolności, jednostka ludzka potwierdza swoją wolność w obrębie sił, które ją ograniczają; stanowi własną formę, opartą na sobie, kształtującą własne życie i tworzącą własne dzieła.

\section{PODSUMOWANIE}

Guardini uznawał Hölderlina za poetę-wieszcza, który jest głęboko zakorzeniony w kulturze i filozofii starożytnej Grecji, antycypując jednocześnie nową epokę historyczną, która nadchodzi. Ważnym elementem twórczości niemieckiego poety i myśliciela jest diagnoza kryzysu religijnego nowożytności. Hölderlin twierdzi, że odeszli bogowie, którzy byli wcześniej, a jeszcze nie ma tych, którzy powinni

29 Tamże, 550. 
nadejść. Gdzie zatem szukać sacrum? Tego, co boskie, należy szukać $\mathrm{w}$ naturze. $\mathrm{W}$ wierszach i poematach tego wybitnego myśliciela i poety szczególną rolę odgrywa natura rozumiana jako przestrzeń, w której zamieszkuje sacrum.

W twórczości Hölderlina następuje ponowne odkrycie sakralnego charakteru natury. $Z$ tego względu niemiecki poeta stanowi dla Guardiniego fazę pośrednią między średniowiecznym teocentryzmem a postmodernistyczną pustynią sakralną - etap, na którym natura, choć nie jest już teofanicznym miejscem transcendentnego Boga, nie stanowi jednak rzeczywistości całkowicie zsekularyzowanej i pozbawionej wymiaru sakralnego. Odkryciu tej przestrzeni przez Hölderlina towarzyszy proces samozamykania się świata egzystencji. Jest on interpretowany przez tego poetę jako największe „Wszystko”, które nie zna żadnych granic. Świat Hölderlina rozciąga się nieskończenie we wszystkie strony. Autor powieści Hyperion dąży do odzyskania dla świata egzystencji także zaświatów z ich królestwem umarłych, które jest nie mniej realne niż królestwo żywych.

Natura w ujęciu Hölderlina jest nie tylko zbiorem rzeczywistości biologicznych czy empirycznych. Aby to, co istnieje, mogło zostać przekształcone w naturę, potrzeba działania ducha, który wprowadza jedność w świat i czyni życie bogatym, głębokim i tajemniczym, czyli boskim. Guardini twierdzi, że w podejściu Hölderlina do natury można dostrzec obecność elementów chrześcijańskich. Jednym z nich jest kategoria ducha, która nawiązuje do chrześcijańskiej postaci Ducha Świętego. Zdaniem Guardiniego traktowanie natury przez Hölderlina można uznać za zsekularyzowaną formę mistyki chrześcijańskiej. Co więcej, niemiecki poeta proponuje nową formę religijności postchrześcijańskiej, która polega na reinterpretacji symboli chrześcijańskich i metamorfozie fenomenu religijnego z rzeczywistości obiektywnej w różnorodne formy zindywidualizowane ${ }^{30}$.

30 Por. M. Strohschneider, Neue Religion in Friedrich Hölderlins später Lyrik, Berlin 2018; K.-H. Ott, Hölderlins Geister, München 2019. 
Guardini twierdzi, że Hölderlin rozpoczął proces tworzenia nowej religijności, który został rozwinięty m.in. w twórczości Rainera Marii Rilkego. Austriacki poeta wyrusza na poszukiwanie sacrum, ponieważ doszedł do wniosku, że dawny Bóg umarł. Rilke, w odróżnieniu od Hölderlina, wyraża religijność zsekularyzowaną, która nie jest otwarta na Objawienie, ale zostaje całkowicie wchłonięta przez rzeczywistość świata. Podczas gdy Hölderlin jest poetą losu człowieka otwartego na transcendencję egzystencjalną, której nie można określić, Rilke redukuje religijność do ziemskiego numinosum. To, co powoli rodziło się w twórczości literackiej Hölderlina, w dziełach Rilkego znajduje swoje dopełnienie: atrybuty transcendentnego Boga zostają wchłonięte przez immanentną rzeczywistość istniejącego świata.

Warto podkreślić, że w połowie XX wieku Guardini zwrócił uwagę na dwa procesy, które także obecnie odgrywają wielką rolę w świecie zachodnim i innych kręgach kulturowych. Pierwszym procesem jest ponowożytne rozumienie natury i kultury, którego istotą są różne formy uprzedmiotowienia tego, co istnieje. Dominacja nauki i techniki oraz współczesna rewolucja biotechnologiczna bardzo często uniemożliwiają dostrzeżenie sakralnego wymiaru natury. Drugim procesem jest sekularyzacja doświadczenia religijnego to, co było transcendentne, staje się immanentne. W konsekwencji atrybuty transcendentnego Boga zostają wchłonięte przez immanentną rzeczywistość istniejącego świata. Diagnozy wypracowane przez Guardiniego kilkadziesiąt lat temu zyskują dzisiaj swoją nową aktualność i pomagają lepiej rozumieć współczesne formy religijności postchrześcijańskiej. Bogata spuścizna intelektualna Hölderlina i Guardiniego wymaga prowadzenia dalszych badań interdyscyplinarnych. Jednym z ważnych i ciekawych obszarów badawczych jest problem wykorzystania w okresie Trzeciej Rzeszy niektórych elementów twórczości literackiej Hölderlina przez zwolenników ideologii narodowego socjalizmu. 


\section{BIBLIOGRAFIA}

Böhmer O.A., Höffe O., Brüder im Geiste - Heidegger trifft Hölderlin, Verlag Karl Alber, Freiburg im Breisgau 2019.

Brencio F., Foundation and poetry. Heidegger as a reader of Hölderlin, Studia Philosophiae Christianae 49(2013)4, 180-200.

Endres M., „Poëtische Individualität“. Hölderlins Empedokles-Ode, De Gruyter Verlag, Berlin 2014.

Gonther U., Schlimme J.E., Hölderlin: Das Klischee vom umnachteten Genie im Turm, Psychiatrie Verlag, Köln 2020.

Guardini R., Hölderlin. Weltbild und Frömmigkeit, Verlag Jakob Hegner, Leipzig 1939.

Guardini R., Das Ende der Neuzeit. Ein Versuch zur Orientierung, Hess Verlag, Basel 1950.

Guardini R., Ethik. Vorlesungen an der Universität München (1950-1962), t. 1-2, Matthias-Grünewald Verlag, Mainz - Paderborn 1993.

Heidegger M., Drogi lasu, tłum. z niem. J. Gierasimiuk i in., Wydawnictwo Aletheia, Warszawa 1997.

Kathrein E., Christentum in apokalyptischer Welt: Eine Anfrage an Friedrich Hölderlin, LIT Verlag, Berlin 2018.

Knoll A., Glaube und Kultur bei Romano Guardini, Ferdinand Schöningh Verlag, Paderborn 1993.

Kobyliński A., Modernità e postmodernità. L'interpretazione cristiana dell'esistenza al tramonto dei tempi moderni nel pensiero di Romano Guardini, Editrice Pontificia Università Gregoriana, Roma 1998.

Kobyliński A., Historia i wolność wedtug Romano Guardiniego, w: Konteksty podmiotowej świadomości, red. R. Moń, E. Podrez, Wydawnictwo Wszechnicy Mazurskiej, Olecko 2003, 217-226.

Kobyliński A., Etos cztowieka prometejskiego. Romano Guardiniego ocena wspótczesnej kultury, władzy i techniki, Społeczeństwo (2005)1, 117-131.

Kobyliński A., Sekularyzacja religii w twórczości Rainera Marii Rilkego i Gianniego Vattima, Studia Philosophiae Christianae 52(2016)3, 27-50.

Ladwein M., Friedrich Hölderlins griechische Seele, Verlag Urachhaus, Stuttgart 2020.

Link J., Hölderlins Fluchtlinie Griechenland, Vandenhoeck Ruprecht Verlag, Göttingen 2020. 
Maj B., Poetica degli elementi e concezioni dell'uomo in „Mnemosyne” (Entwurf) di Friedrich Hölderlin, in: Natura e sentimenti, a cura di R. Milani, Edizioni Nike, Milano 2000, 55-62.

Nyske E., Język neopentekostalny. Strategie konwersacyjne interlokutorów, Przegląd Religioznawczy 271(2019)1, 159-175.

Oesterle K., Wir \& Hölderlin? Was der größte Dichter der Deutschen uns 250 Jahre nach seiner Geburt noch zu sagen hat, Klöpfer Narr Verlag, Tübingen 2020.

Ott K.-H., Hölderlins Geister, Carl Hanser Verlag, München 2019.

Penzo G., L'interpretazione di Hölderlin in Romano Guardini, filosofo dell'esistenza, w: La Weltanschauung cristiana di Romano Guardini, red. S. Zucal, Edizioni Dehoniane, Bologna 1988, 449-470.

Safranski R., Hölderlin: Komm! ins Offene, Freund! Biographie, Carl Hanser Verlag, München 2019.

Schmidt Th., Hölderlin 2020. Das Jubiläumsjahr: Programm, Verlag Deutsche Schillergesellschaft, München 2020.

Stavru A., Hölderlin und die „Flucht des Göttlichen“. Martin Heidegger und Walter F. Otto in Rom (1936-1937), Studi Germanici 39(2001)2-3, 269-310.

Strohschneider M., Neue Religion in Friedrich Hölderlins später Lyrik, De Gruyter Verlag, Berlin 2018.

Szumani E., Teologiczna koncepcja natury w „Hyperionie” Hölderlina, w: Arcydzieła literatury niemieckiej. Szkice, komentarze, interpretacje, red. E. Białek, G. Kowal, Oficyna Wydawnicza Atut, Wrocław 2011, 1-12.

Witschke E., Hegel, Hölderlin, Schelling: Roman einer Männerfreundschaft, Klöpfer Nar Verlag, Tübingen 2019.

\section{WHAT IS THE SACRED REALM OF NATURE? A PHILOSOPHICAL INTERPRETATION OF FRIEDRICH HÖLDERLIN'S WORKS IN THE WRITINGS OF ROMANO GUARDINI}

\footnotetext{
Abstract. The principal objective of this article is to introduce the sacred realm of nature, discussed by Romano Guardini (1885-1968) in the philosophical works he devoted to the interpretation of the writings of Friedrich Hölderlin (1770-1843). Guardini conducted his research on Hölderlin's output in the philosophy of religion. With respect to Hölderlin's poems, Guardini noted the special role played in them by nature understood as the space inhabited by the sacrum. In fact, Hölderlin's literary works are pervaded with a new form of Post-Christian religiosity, which consists in the practice of re-interpreting Christian symbols and translating the religious phenomenon from one objective reality to various, individualized forms.
} 
Keywords: nature, sacrum, religion, modernity, postmodernity, religious experience, secularization, post-Christian religiosity

ANDRZEJ KOBYLIŃSKI

a.kobylinski@uksw.edu.pl

Uniwersytet Kardynała Stefana Wyszyńskiego w Warszawie, Instytut Filozofii

Wóycickiego 1/3, 01-938 Warszawa

ORCID: 0000-0003-2252-8634

DOI: 10.21697/spch.2020.56.1.01 